\title{
EXPERIMENTÁLNÍ TESTOVÁNÍ \\ PREFABRIKOVANÝCH SCHODIŠ Ť Z KOMPOZITNÍCH MATERIÁLŮ NA BÁZI CEMENTU A ORGANICKÝCH VLÁKEN
}

\author{
EXPERIMENTAL TESTING OF PREFABRICATED STAIRS MADE OF \\ COMPOSITE MATERIALS BASED ON CEMENT AND ORGANIC FIBERS
}

Ondřej Nespěšný ${ }^{*}, 1$, Jan Vystrčil ${ }^{1}$, Dominik Cak1 ${ }^{1}$

*ondrej.nespesny@vut.cz

${ }^{1}$ Vysoké učení technické v Brně, Fakulta stavební, Veveří 331/95, 60200 Brno

\begin{abstract}
Abstrakt
Schodiště jsou nedílnou součástí vícepodlažních budov a musí splňovat řadu požadavků vycházejících zejména z technických norem. Jedním ze základních požadavků na stavby je mechanická odolnost a stabilita, která je v současnosti často ověřována výpočtovými metodami. Pokud jsou výpočtové metody nedostačující musí být využíváno experimentální metody zatěžování konstrukcí, kterou popisuje tato publikace. Př́íspěvek shrnuje průběh statického zatěžování prefabrikovaných schodištových sestav z kompozitních materiálů na bázi cementu a výztužných organických vláken. Aplikované metody vycházejí z evropských technických norem a řídících pokynů pro evropská technická schválení.
\end{abstract}

\section{Klíčová slova}

Schodiště, experimentální testování, statické zatěžování, kompozitní materiály

\begin{abstract}
Stairs are an integral part of multi-storey buildings and must meet a few ones based mainly on technical standards. One of the basic requirements for buildings is mechanical resistance and stability, which is currently often verified by calculation methods. If the calculation methods are insufficient, the experimental methods of loading the structures described in this publication must be used. The paper summarizes the course of static loading of prefabricated stair assemblies made of composite materials based on cement and reinforcing organic fibers. The applied methods are based on European standards and guidelines for technical technical approval.
\end{abstract}

Key words

Staircase, experimental testing, static loading, composite material

\section{1 ÚVOD}

Kompozitní desky na bázi cementu a organických vláken (označovány jako cementovláknité desky) jsou dnes environmentálním, univerzálním a trvanlivým stavebním materiálem. Slouží jako náhrada př́rodního dřeva a výrobků ze dřeva, jako jsou např́klad překližky, nebo desky s orientovanými vlákny (OSB). Vlastnosti cementovláknitých desek, jako stavebního materiálu umožňují různorodá použití v širokém spektru stavebních konstrukcí. Mezi ty nejčastější patři fasádní obklady větraných fasád pro rekonstrukce i novostavby, vnitřní a vnější podhledy, obklady vnitřních a vnějších konstrukcí, kabelové mosty či konstrukce požární ochrany.

Jednou z teoreticky možných oblastí použití cementovláknitých desek je využití v rámci konstrukcí pozemních staveb ve formě interiérových schodišt' [1], na která je kladena řada požadavků. Tyto požadavky jsou v České republice dány obecně závaznými předpisy [2], [3]. 


\section{LITERÁRNÍ PŘEHLED/POPIS SOUČASNÉHO STAVU}

Základními požadavky na stavby, tedy i na schodiště stanovuje v České republice vyhláška č. 268/2009 Sb., [2], která uvádí, že konstrukce musí být navržena a provedena tak, aby byla vhodná při respektování hospodárnosti pro zamýšlené využití a aby současně splnila (př̌i běžné údržbě a působení běžně předvídatelných vlivů po dobu předpokládané existence) základní požadavky, kterými jsou:

- Mechanická odolnost a stabilita,

- požární bezpečnost,

- ochrana zdraví, zdravých životních podmínek a životního prostředí,

- ochrana proti hluku

- bezpečnost při užívání

- úspora energie a ochrana tepla.

Současně je v [2] uvedeno, že konstrukce schodiště nesmí způsobit náhlé nebo postupné zřícení nebo destruktivní poškození vlastní, nebo přilehlé stavby a nesmí dojít $\mathrm{k}$ nepřípustnému přetvoření, které může narušit stabilitu, mechanickou odolnost, trvanlivost nebo uživatelnost. Ř́dící pokyn pro evropská technická schválení pro prefabrikované schodištové sestavy [3] uvádí, že konstrukce schodiště musí být navržena a provedena takovým způsobem, aby zatížení, která na ni budou pravděpodobně působit v průběhu výstavby a uživání neměla za následek:

- Zř́ícení celé stavby nebo její časti,

- větši stupeň nepř́ípustného přetvoření,

- poškození jiných částí stavby nebo technických zařízení nebo instalovaného vybavení v důsledku většího přetvoření nosné konstrukce,

- poškození v případě, kdy je rozsah neúměrný původní príicině.

Statickou únosnost schodiště lze prokázat numerickou analýzou, nebo statickou zatěžovací zkouškou (fullscale) jako Pěnčík v [4], kde bylo analyzováno dřevěné segmentové schodiště z buku lesního (Fagus sylvatica), dubu zimního (Quercus petrea), borovice lesní (Pinus sylvestris) a smrku (Picea abies). Podle Sachse [5] je mimo statického zatížení konstrukce schodiště, často věnována pozornost i vibracím vyvolaným člověkem, tzn. dynamické účinky na konstrukci. Hodnocení dynamického chování ocelových schodišt na přítomnost osob publikoval Cappellini v [6], kde aplikovali metodiku kvantifikace změn modálních parametrů v důsledku přitomnosti pasivních lidí na štíhlé konstrukci [7]. Dynamické testy lze považovat za pokročilý stupeň analýzy konstrukce, kterým předchází statická zatěžovací zkouška, full-scale experiment, nebo numerická simulace. Fullscale experiment lze považovat za jednu z nejpřesnějších metod pro ověřní chování konstrukce, nebo materiálu. Ve výzkumu v oblasti stavebnictví metoda ověření full-scale experimentem velmi oblíbená, což potvrzuje řada nedávných vědeckých publikací [8], [9] a [10]. Průběh full-scale experimentu prezentují autoři i v rámci této publikace.

\section{METODIKA}

Prezentovaná metoda experimentálního testování konstrukcí segmentových schodišt’ za účelem ověření statické únosnosti uvažuje hodnoty zatížení a dílčích součinitelů bezpečnosti materiálů $\gamma_{M}$ podle ČSN EN 1991-1-1 Eurokód 1: Zatížení konstrukcí - Část 1-1: Obecná zatížení - Objemové tíhy, vlastní tíha a užitná zatížení pozemních staveb [2] a řídícího pokynu pro evropská technická schválení pro prefabrikované schodištové sestavy [3]. Prezentovaná metodika byla aplikována na konstrukci jednoramenného segmentového schodiště z cementovláknitých desek na bázi cementu a organických vláken. Metodika je zaměřena na interiérová schodiště, tzn. že jsou uvažovány běžné podmínky vnitřního prostř̌edí s teplotami kolísajícími mezi $+5{ }^{\circ} \mathrm{C}$ až $+30{ }^{\circ} \mathrm{C}$ a relativními vlhkostmi kolísajícími mezi $30 \%$ až $70 \%$.

Zatěžovací zkouška je ze statického hlediska prováděna za nejméně př́znivých podmínek. Schodištové rameno je řešeno jako prostý nosník s kloubovým uložením v horní části, kde kloubové uložení simulují prolisované L-úhelníky z pozinkované, nebo nerezové oceli o rozměrech minimálně $65 \times 90 \times 90 \times 2,5 \mathrm{~mm}$ se závitovými tyčemi o průměru $10 \mathrm{~mm}$, viz Obr. 1 . Posuvnou podporou v patě simuluje ocelová tyč o průměru 10 mm. Ke kontinuálnímu zaznamenávání svislých posunů při statickém zatěžování se doporučuje použití potenciometrických lankových snímačů s měřícím rozsahem 0-500 mm [11], měřící rozsah je možné prodloužit pomocí nerezového ocelového lanka [11]. 
Svislý posun $U_{y}$ je zaznamenáván na nosných prvcích (schodnicích) schodiště, minimálně v 1/3, 1/2 a 2/3 délky nosného prvku a u kloubové podpory z důvodu záznamu jejího poklesu. Alternativním způsobem zaznamenávání svislých posunů schodnic je aplikace systému prostorového měření v reálném čase [12].
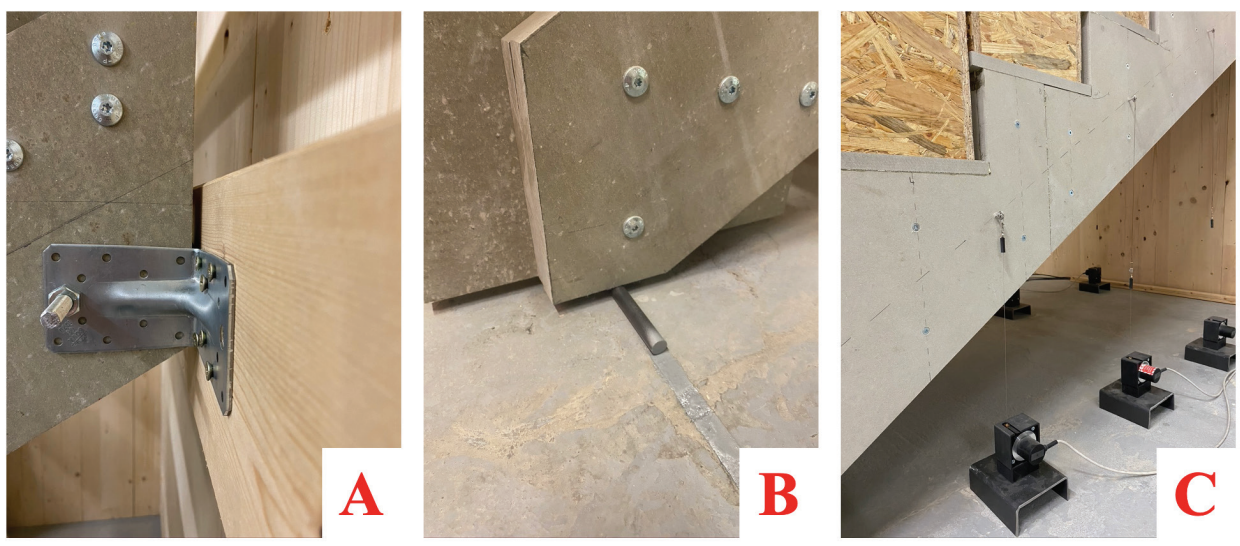

Obr. 1 Kloubové uložení schodištového ramene pomocí ocelového L-úhelníku (A), posuvná podpora v patě schodiště (B), sada potenciometrických lankových snímačů dráhy (C).

Zatížení na konstrukci schodiště o vlastí hmotnosti $G_{k}$ je uvažováno jako rovnoměrné spojité. V reálném případě je obtížné rovnoměrné spojité zatížení simulovat. Největším přiblížením reálného stavu je zatěžování konstrukce pomocí vaků naplněných kapalinou o známé hmotnosti. Alternativním způsobem je krokové zatěžování vaky s pískem frakce $0 / 4 \mathrm{~mm}$, nebo kačírkem frakce $4 / 8 \mathrm{~mm}$, které jsou postupně ukládány do OSB boxů o rozměrech stupnice.

Hmotnost zatěžovacích vaků, je stanovena na základě plošného rozměru schodiště, zatížení stanovené podle [2] je $V=3,0 \mathrm{kN} / \mathrm{m}^{2}$. Hodnota koeficientu $\gamma_{M}$ [-] je podle [3] závislá na materiálu konstrukce schodiště. Pro výrobky ze dřeva a na bázi dřeva je uvažována hodnota $\gamma_{M}=1,3$, pro betonové prvky pojené cementem nebo pryskyřicí je $\gamma_{M}=1,5$, pro ocelové konstrukce schodiště je $\gamma_{M}=1,1$. Na základě hodnoty součinitele $\gamma_{M}$ je stanoveno zatěžovací schéma.

Statická zatěžovací zkouška je rozdělena do dvou fází - zatěžování a odtěžování. Cyklus zatížení a odtížení je nezbytné opakovat celkem dvakrát. Mezi jednotlivými fázemi, resp. mezi jednotlivými zatěžovacími kroky, tj. $1,0 \times V, 1,3 \times V$ a $1,5 \times V$ je přestávka $\mathrm{v}$ délce 15 minut, které je uvažována $\mathrm{z}$ důvodu ustálení konstrukce schodiště, resp. ustálení svislých posunů $U_{y}[\mathrm{~mm}]$ a možnosti sledovat relaxaci konstrukce v čase. První a druhé zatěžování probíhá podle schématu: $G_{k} \rightarrow 1,0 \times V \rightarrow 1,3 \times V \rightarrow 1,5 \times V \rightarrow 1,3 \times V \rightarrow 1,0 \times V \rightarrow G_{k}$. V případě stanovení maximálního možného zatížení, tzn. do ztráty stability se postupuje podle zatěžovacího schématu: $G_{k} \rightarrow 1,0 \times V \rightarrow 1,3 \times V \rightarrow 1,5 \times V \rightarrow$ zhroucení konstrukce. Př́́klad rozdělení zatěžovacích vaků pro jednoramenné schodiště o 9. stupních se stupnicemi o plošných rozměrech $900 \times 300 \mathrm{~mm}$ je uveden v Tab. 1 .

Tab. 1 Př́klad rozdělení zatížení podle zatěžovacích kroků na jednotlivé schodišt'ové stupně 1-9.

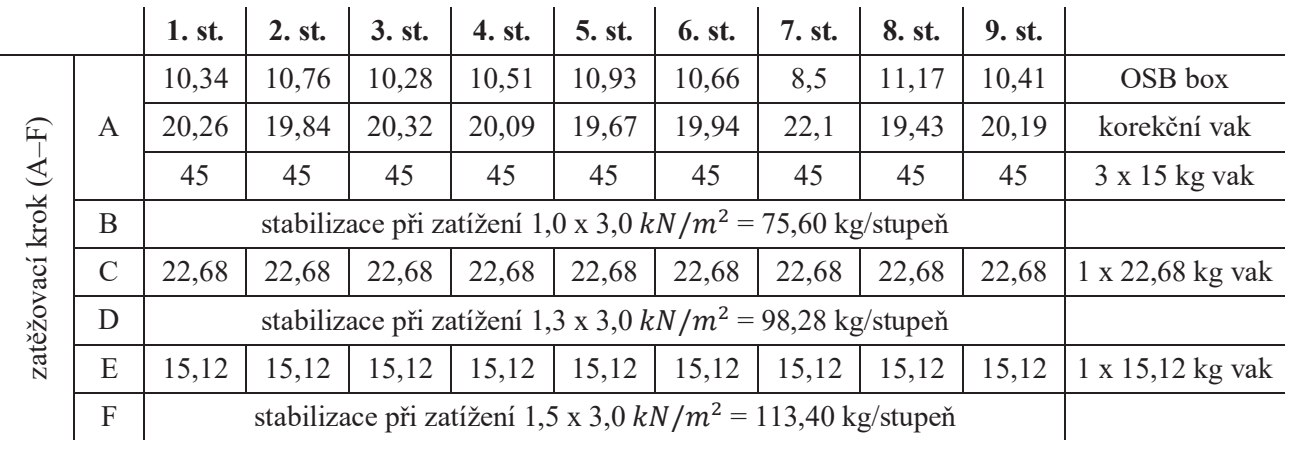

Schodišt'ové stupně jsou v každém zatěžovacím kroku zatěžovány na základě optimalizačního výpočtu. Cílem je umist'ovat zatěžovací boxy v takovém pořadí, aby se průběh ohybového momentu od působícího zatížení co 
nejvíce přiblížil průběhu ohybového momentu od spojitého rovnoměrného zatížení, tj. parabola druhého stupně $\mathrm{s}$ maximální hodnotou v polovině rozpětí. Př́iklad zatěžování jednoramenného schodiště o 9. stupních je uveden na Obr. 2.
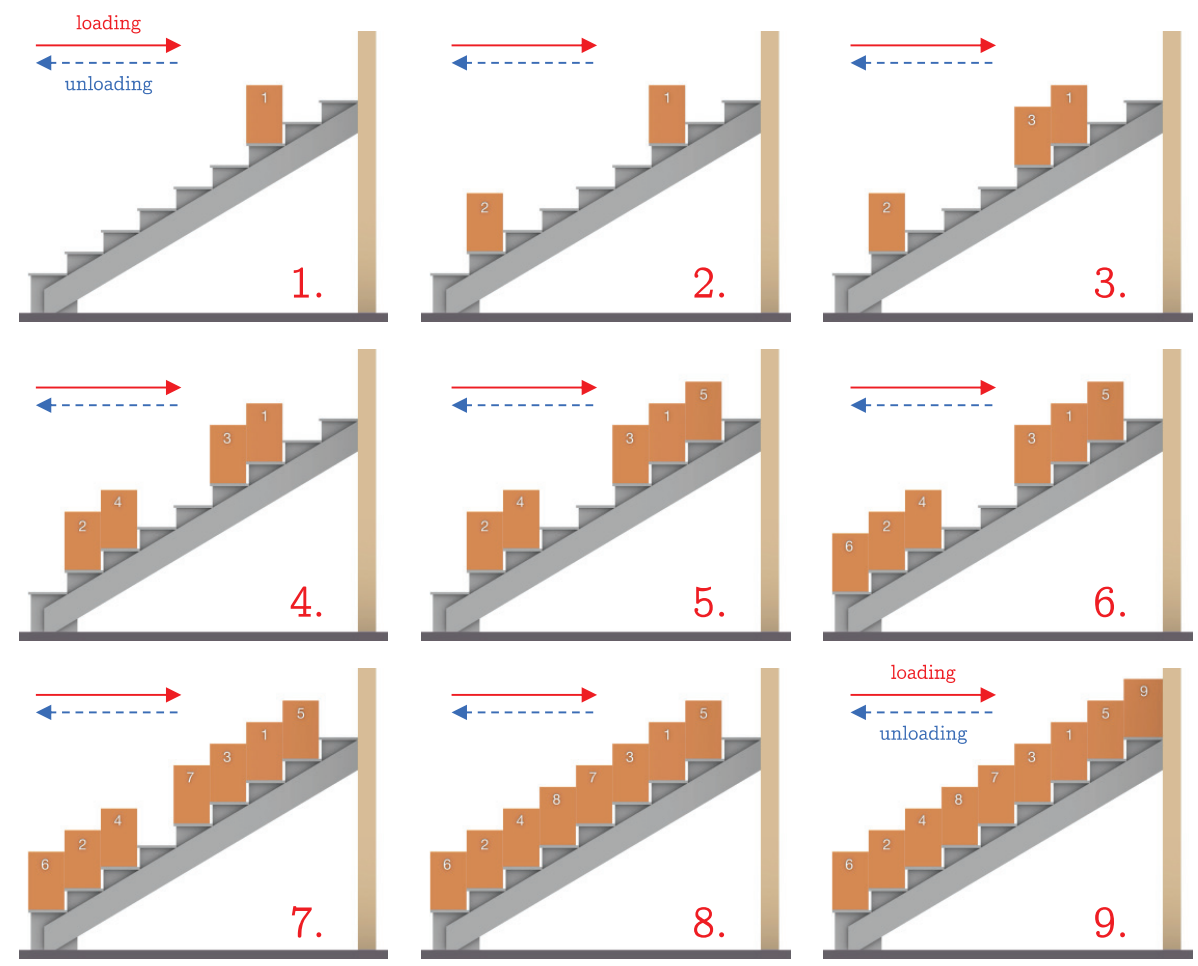

Obr. 2 Příklad postupného zatěžování jednoramenného schodiště s 9. stupni - zatížení (červeně), odtížení (modře).

\section{VYHODNOCENII EXPERIMENTU}

Výstupy ze zatěžování konstrukce schodiště podle uvedené metodiky jsou rozděleny do kategorií:

- Mechanická odolnost/únosnost a stabilita,

- Chování při zatížení/posuvu.

Únosnost je uváděna jako přepočtená hmotnost na jeden schodišt’ový stupeň, resp. stupnici v $k N$. Současně je výstupem přepočtené zatížení na celé schodištové rameno v $k N$ při porušení konstrukce, nebo jako prokázání dosažení požadovaných hodnot.

Chování při zatížení, resp. posuvu je uváděno v mm vztaženo k měřícímu bodu na konstrukci. Vyhodnocuje se průhyb konstrukce při odpovídajícím zatížení v odpovídajícím zatěžovacím kroku a výsledný průhyb konstrukce při maximálním zatížení. Při provozních zatíženích se průhyb schodiště uvádí ve vztahu ke středové čáře ramene $l[\mathrm{~mm}]$. Průhyb nesmí přesáhnout hodnotu $l / 200$. Únosnost spojovacích prostředků je předmětem samostatného měření.

\section{Poděkování}

Př́spěvek vznikl za podpory projektu FAST-J-21-7449 "Stanovení materiálového modelu kompozitního materiálu tvořeného cementovou matricí s rozptýleními výztužnými organickými vlákny nebo anorganickými vlákny 
s ohledem na směr zatěžování" a FAST-S-21-7422 "Studium tepelně vlhkostních procesů v 3D tištěných konstrukcí pozemních staveb".

\section{Použité zdroje}

[1] NESPĚŠNÝ, Ondřej, Jan PĚNČÍK, David BEČKOVSKÝ, Jan VYSTRČIL a Karel ŠUHAJDA. Determination of material and elasticity constants of cement fibre boards to extend field of application. Construction and Building Materials. 2021, 306. ISSN 09500618. Dostupné z: doi:10.1016/j.conbuildmat.2021.124821

[2] ČSN EN 1991-1-1-1 - Eurokód 1: Zatížení konstrukcí - Část 1-1: Obecná zatížení - Objemové tíhy, vlastní tíha a užitná zatížení pozemních staveb. Praha, 2004.

[3] ETAG 008: Prefabricated Stair Kits. Brusel: European Organisation for Technical Approvals, 2000.

[4] PĚNČÍK, Jan, Miloš LAVICKÝ, Pavel KRAL a Zdeňka HAVÍŘOVÁ. Analysis of Behaviour of Prefabricated Staircases with One-Sided Suspended Stairs. Drvna industrija. 2015, 66(2), 147-156. ISSN 00126772. Dostupné z: doi:10.5552/drind.2015.1338

[5] SACHS

[6] CAPPELLINI, A., S. MANZONI, M. VANALI a A. CIGADA. Evaluation of the dynamic behaviour of steel staircases damped by the presence of people. Engineering Structures. 2016, 115, 165-178. ISSN 01410296. Dostupné z: doi:10.1016/j.engstruct.2016.02.028

[7] BUSCA, G., A. CAPPELLINI, S. MANZONI, M. TARABINI a M. VANALI. Quantification of changes in modal parameters due to the presence of passive people on a slender structure. Journal of Sound and Vibration. 2014, 333(21), 5641-5652. ISSN 0022460X. Dostupné z: doi:10.1016/j.jsv.2014.06.003

[8] FLEMING, Patrick H. a Michael H. RAMAGE. Full-scale construction and testing of stress-laminated columns made with low-grade wood. Construction and Building Materials. 2020, 230. ISSN 09500618. Dostupné z: doi:10.1016/j.conbuildmat.2019.116952

[9] ZUO, Zibo, Jian GONG, Yulin HUANG, Yijian ZHAN, Ming GONG a Lulu ZHANG. Experimental research on transition from scale $3 \mathrm{D}$ printing to full-size printing in construction. Construction and Building Materials. 2019, 208, 350-360. ISSN 09500618. Dostupné z: doi:10.1016/j.conbuildmat.2019.02.171

[10] LI, Bin, Hongyuan FANG, Hang HE, Kangjian YANG, Can CHEN a Fuming WANG. Numerical simulation and full-scale test on dynamic response of corroded concrete pipelines under Multi-field coupling. Construction and Building Materials. 2019, 200, 368-386. ISSN 09500618. Dostupné z: doi:10.1016/j.conbuildmat.2018.12.111

[11] MICRO-EPSILON [online]. 2021 [cit. 2021-12-04]. Dostupné z: https://www.microepsilon.cz/download/products/cat--wireSENSOR--en.pdf

[12] X-SIGHT [online]. 2021 [cit. 2021-12-04]. Dostupné z: https://www.xsight.eu/dicsystems/ 